Australian Journal of

Crop Science

\title{
Water and nitrogen water use efficiency in forage palm irrigated with salt water in
} the Neossolo

\section{Patrícia Ferreira da Silva*, Rigoberto Moreira de Matos, José Dantas Neto, Vitória Ediclécia Borges, Thiago Galvão Sobrinho, Semako Ibrahim Bonou, Carlos Alberto Vieira de Azevedo, Vera Lúcia Antunes de Lima, Arsênio Pessoa de Melo Júnior}

\author{
Federal University of Campina Grande, Academic Unit of Agricultural Engineering, Campina Grande, 58.109- 970, \\ Paraíba, Brazil
}

\author{
*Corresponding author: patrycyafs@yahoo.com.br
}

Abstract

\begin{abstract}
The objectives were to analyze the water and nitrogen use efficiency by forage palm in different irrigation depths with saline water and nitrogen fertilization levels in the Brazilian semi-arid region. The experiment was conducted under field condition during one year of cultivation (360 days). The experimental design was a complete randomized block and $5 \times 5$ factorial scheme with five irrigation depths $\left(125,100,75\right.$, and $25 \%$ of $\left.\mathrm{ET}_{0}\right)$ and five levels of nitrogen fertilization $\left(0,150,300,450\right.$ and $600 \mathrm{~kg} \mathrm{ha}^{-1}$ of $\left.\mathrm{N}\right)$ and three replicates. Irrigation and acceptable nitrogen fertilization resulted in a good water and fertilization management. Water and nitrogen use efficiency of forage palm were higher, when water depths and the nitrogen levels supplied to the soil were increased. The $125 \% \mathrm{ET}_{0}$ depth showed a higher efficiency of water and nitrogen use in the forage palm during 360 days of study. In conditions of low nitrogen supply, the efficiency of nitrogen use is directly and indirectly associated with the fresh mass yield; while under high supply, the efficiency of the use of nitrogen is more effective. The use of irrigation and nitrogen fertilization in the semi-arid region is recommended to obtain higher productivity of water and nitrogen from the forage palm.
\end{abstract}

Keywords: dripping; fertirrigation; nitrogen levels; Opuntia sp.; rational use of water.

Abbreviations: $\mathrm{pH}-\mathrm{H}_{2} \mathrm{O} \_$soil hydrogenation potential in water; OM_organic matter; N_nitrogen; $\mathrm{P} \_$phosphorus; $\mathrm{K} \_$potassium; Ca_ Calcium; Mg_magnesium; Na_sodium; H+_hydrogen; $\mathrm{Al}^{3+}{ }_{-}$Aluminum; SB_sum of bases; and CEC_cation exchange capacity; $\mathrm{ET}_{0 \_}$reference evapotranspiration; WUE_water use efficiency; NUE_nitrogen use efficiency; DM_dry mass; MV_fresh mass; MEE_MexicanElephantEar; DAT_Days after application of treatments.

\section{Introduction}

In the semi-arid region, the seasonality of weather elements, makes animal feed production a constant challenge both at inter-annual as well as intra-annual scale (Dubeux Júnior et al. 2010). The use of adequate irrigation and fertilization management strategies is of paramount importance, especially regarding to the use of water deficit resistant species in order to supplement the crop demand during the dry season, providing roughage food to the herds (Silva et al., 2015).

Because it is a cactus, forage palm is well adapted to arid and semi-arid regions, displaying tolerance to long drought periods and high water use efficiency (Dubeux Júnior et al., 2010; Pinheiro et al., 2014; Silva et al., 2015). It is regarded as one of the main forage subsistence resources of cattle breeding in the northeastern region of Brazil, considering its relevance in feeding of the main herds as a source of water, energy and minerals (Almeida et al., 2012). The semi-arid region holds little availability of water and much of it has poor quality. Lowquality waters, especially with high salt concentrations, are poorly used in agriculture, but they can be used satisfactorily in forage palm production (Dubeux Júnior et al., 2010).

Dubeux Júnior et al. (2013) state that in Brazil, approximately 600.000 ha are currently cultivated with forage palm, with an estimated yield of fresh mass per hectare planted of 600 tons, when submitted to fertilization and a densified crop system. Morais and Vasconcelos (2007), reported that this forage stands out as a juicy, bulky food with high acceptability and a large coefficient of dry matter digestibility, an important factor for the herds.

For Hernández et al. (2004), stated that irrigation in forage palm crops in northeastern Brazil is a technique of great importance. However, its proper implementation and management depends upon information of the water 
requirement by the crop, which is a function of atmospheric demand, soil water content and plant resistance to the transfer of water to the environment, contributing to the increment in the yield of such crop (Silva et al., 2010; Payero and Irmak, 2008; Billesbach, 2011; Ghiberto et al., 2011; Evett et al., 2012; Silva et al., 2016).

The input of external sources of fertilization, especially nitrogen, is essential for raising the biomass yield of the forage palm to allow positive impacts on the profitability of the productive system. However, only 40 to $60 \%$ of the applied mineral nitrogen is absorbed by the forage (Cunha et al., 2012).

Water use efficiency of such crop with Crassulacean Acid Metabolism is as many as 11 times as that observed in C3 mechanism plants, making the palm one of the most adapted species to the semi-arid among the cropped forage plants (Alves et al., 2007).

For that reason, indicators of water (WUE) and nitrogen (NUE) use efficiency by the plants is one of the ways to analyze crop response to different water and nutrient availability conditions as it relates the production of dry biomass or commercial production with the amount of water applied or evapotranspirated by the crop, as well as the amount of absorbed nutrient (Souza et al., 2011).

So, the improvement in the nitrogen use efficiency (NUE) is essential for the development of sustainable agriculture. This efficiency is the relationship between yield in dry biomass or the commercial part and the amount of soil available or applied nitrogen (Moll et al., 1982).

Thus, the objective of this study was to evaluate the water and nitrogen use efficiency in forage palm submitted to different irrigation depths with saline water and nitrogen fertilization doses in the Brazilian semi-arid region.

Results

\section{Water consumption in the period}

The water volume applied in the irrigations as a function of the treatments during the experiment is shown in Table 1 . It is observed that the volume of the applied water increased over forage palm ontogeny, and the average $\mathrm{ET}_{0}$ set during the cycle was $7.6 \mathrm{~mm}$. The difference between the lowest and the largest accumulated irrigation depth was $276.9 \mathrm{~mm}$. Such difference results in better outcomes for the yield of Mexican Elephant Ear cultivar, when L1 is compared to L5. The total precipitation during this experiment period was $446.9 \mathrm{~mm}$.

An increase in the depth is observed over the crop cycle, a fact that can be justified by the increment of the water consumption by the plants, which favored their performance in both growth and yield, and in the efficient use of water (Table 1).

\section{Water and nitrogen use efficiency for the isolated effects}

The linear mathematical model best fitted the efficient use of water and nitrogen in the first crop cycle (Figure 1). It was observed that as the irrigation depth and the nitrogen levels increased, a positive increment was obtained in the efficient use of water (Figure 1A) as well as in the efficient use of nitrogen (Figure 1B).

The rise in the efficient use of water at every $25 \% \mathrm{ET}_{0}$ was 1.18 $\mathrm{kg} \mathrm{m}^{-3}$. Moreover, it can be observed that for fresh mass yield (MV) at the order of $394 \mathrm{t} \mathrm{ha}^{-1}$ in the $125 \% \mathrm{ET}_{0}$ depth, the water use efficiency was $61.12 \mathrm{~kg} \mathrm{H}_{2} \mathrm{O} \mathrm{kg} \mathrm{MV}$, equivalent to $16.36 \mathrm{~kg} \mathrm{MV} \mathrm{m}^{-3}$ of irrigation water (Figure $1 \mathrm{~A}$ ), considering that dry mass (DM) yield is $20 \%$ of the fresh mass for a productivity of $78.8 \mathrm{tha}^{-1} \mathrm{DM}$, and water use efficiency equal

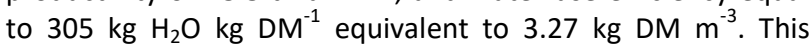
increase in water use efficiency is directly related to the increase in fresh mass yield as a function of the applied irrigation depth.

Nitrogen use efficiency was incremented at every $150 \mathrm{~kg} \mathrm{~N} \mathrm{ha}^{-1}$ per $0.18 \mathrm{~kg}$ of fresh matter per $\mathrm{kg} \mathrm{N}^{-1}$ applied in the soil, in which the maximum efficiency of the nitrogen use was obtained at the levels of $600 \mathrm{~kg} \mathrm{ha}^{-1}$, corresponding to $445 \mathrm{t} \mathrm{ha}$ 1 , allowing an efficiency of $0.74 \mathrm{~kg}$ of fresh mass per $\mathrm{kg} \mathrm{N}^{-1}$ (Figure 1B). This means that forage palm reached its capacity to absorb and use $\mathrm{N}$ of the soil as the amount of nitrogen supplied to the soil, which incremented its productivity. In addition, it is noted that productivity as a function of the irrigation depth was lower than the yield obtained as a function of the levels of nitrogen applied to the soil. A fact that is likely to be related to the high content of salts in the irrigation water.

\section{Water and nitrogen use efficiency over the crop cycle}

Water use efficiency (WUE) due to irrigation depth (\% $\mathrm{ET}_{0}$ ) and the days following the application of the treatments was modeled by the response surface $\left(R^{2}=0.94\right)$. It can be noted that the lowest efficiency in water use $(23.4 \mathrm{~mm})$ was verified at the association of $25 \% \mathrm{ET}_{0}$ depth $(23.4 \mathrm{~mm})$ at 30 days after application of the treatments (Figure 2), a fact that may be related to the lower yield observed in this treatment $\left(89 \mathrm{t} \mathrm{ha}^{-1}\right)$ and water use efficiency equal to $0.91 \mathrm{~kg} \mathrm{MV} \mathrm{m}^{-3}$. At irrigation depth of $125 \% \mathrm{ET}_{0}(818.0 \mathrm{~mm})$ a yield of $880 \mathrm{t} \mathrm{ha}^{-1}$ and water use efficiency of $15.26 \mathrm{~kg} \mathrm{MV} \mathrm{m}^{-3}$, equivalent to $65 \mathrm{~kg} \mathrm{H}_{2} \mathrm{O} \mathrm{kg}$ $\mathrm{MV}^{-1}$ (Figure 2) were achieved 360 days after application of the treatments (DAT). This behavior can be explained by high productive response presented by the forage palm to the increment of irrigation depth. It was possible to quantify nitrogen use efficiency as a function of the nitrogen levels applied by fertigation and the days after the application of each treatment (DAT) on the basis of the equation that modeled, the nitrogen use efficiency over the ontogeny (Figure $3)$. The highest nitrogen use efficiency was obtained at the level of $600 \mathrm{~kg} \mathrm{ha}^{-1} \mathrm{~N}$ at 360 days after the application of $\mathrm{N}$ levels, corresponding to an efficiency of $1.87 \mathrm{~kg}$ of fresh matter per $\mathrm{kg}$ of nitrogen applied in the soil, with a yield of $975 \mathrm{t} \mathrm{ha}^{-1}$. The percentage difference between the largest and the smallest treatment was $18.18 \%$ (Figure 3).

\section{Discussion}

Queiroz et al. (2015) reported an applied volume per depth of 976; 1048; 1096; 1152 and $1202 \mathrm{~mm}$, with a difference between the lowest and highest supplied depths of only 226 $\mathrm{mm}$. As a result, the imposed irrigation depths did not 
Table 1. Volume of water applied via irrigation in experimental period for each and total depth.

\begin{tabular}{lccccc}
\hline Depths & \multirow{2}{*}{$\mathrm{ET}_{0}(\%)$} & $\begin{array}{c}\mathrm{AV}+\mathrm{R}(\mathrm{mm}) \\
\text { 30 DAT }\end{array}$ & $\begin{array}{c}\mathrm{AV}+\mathrm{R}(\mathrm{mm}) \\
90 \mathrm{DAT}\end{array}$ & $\begin{array}{c}\mathrm{AV}+\mathrm{R}(\mathrm{mm}) \\
\text { 150 DAT }\end{array}$ & $\begin{array}{c}\text { AV+R }(\mathrm{mm}) \\
\text { 360 DAT }\end{array}$ \\
\hline L1 & 25 & 23.4 & 48.8 & 294.2 & 541.1 \\
$\mathrm{~L} 2$ & 50 & 46.8 & 93.7 & 354.3 & 615.3 \\
$\mathrm{~L} 3$ & 75 & 70.3 & 140.6 & 408.6 & 669.5 \\
$\mathrm{L4}$ & 100 & 93.7 & 187.5 & 458.3 & 743.8 \\
$\mathrm{~L} 5$ & 125 & 117.1 & 243.3 & 513.0 & 818.0 \\
\hline
\end{tabular}

$A V=$ applied volume; $\mathrm{R}=$ rainfall; $\mathrm{DAT}=$ days after treatment application.
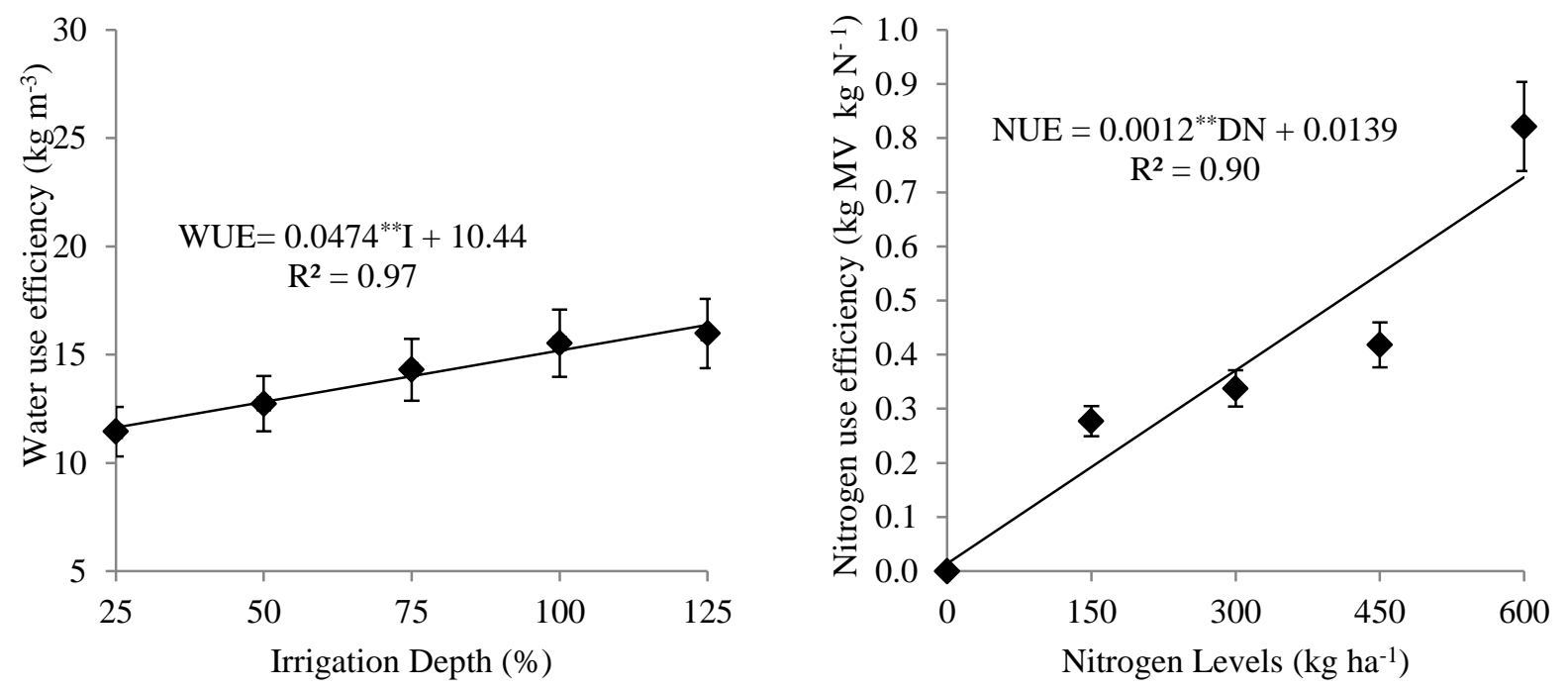

Fig 1. Water and agronomic use efficiency as a function of the irrigation depths (A) and nitrogen and agronomic use efficiency as a function of the applied nitrogen levels (B).

Table 2. Chemical, physical and water characterization of the soil in the experimental area at $0.0-0.20 \mathrm{~m}$ layer.

\begin{tabular}{|c|c|c|c|c|c|c|c|c|c|c|c|c|c|}
\hline \multirow{3}{*}{\multicolumn{2}{|c|}{ Layer (m) }} & \multicolumn{12}{|c|}{ 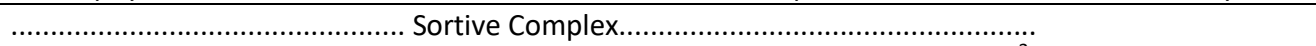 } \\
\hline & & \multirow{2}{*}{$\mathrm{pH}-\mathrm{H}_{2} \mathrm{O}$} & OM & $\mathrm{N}$ & $\mathrm{P}$ & $\mathrm{K}$ & $\mathrm{Ca}$ & $\mathrm{Mg}$ & $\mathrm{Na}$ & $\mathrm{H}+$ & $\mathrm{Al}^{3+}$ & SB & $\mathrm{CeC}$ \\
\hline & & & \multicolumn{11}{|c|}{ 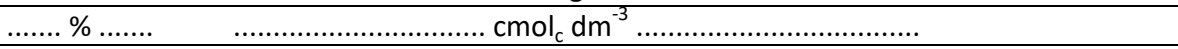 } \\
\hline $0.0-0.20$ & & 5.83 & 0.38 & 0.02 & 4.75 & 0.60 & 4.18 & 2.48 & 0.17 & 0.18 & 0.00 & 7.43 & 7.61 \\
\hline \multicolumn{3}{|c|}{ Granulometry (\%) } & \multirow{2}{*}{\multicolumn{2}{|c|}{$\begin{array}{l}\text { Porosity } \\
(\%)\end{array}$}} & \multirow{2}{*}{\multicolumn{2}{|c|}{$\begin{array}{l}\text { Soil Density } \\
\left(\mathrm{g} \mathrm{cm}^{-3}\right)\end{array}$}} & & \multirow{2}{*}{\multicolumn{3}{|c|}{$\begin{array}{l}\text { Density of particles } \\
\left(\mathrm{g} \mathrm{cm}^{-3}\right)\end{array}$}} & \multirow{2}{*}{\multicolumn{3}{|c|}{ Available Water (\%) }} \\
\hline Sand & Silt & Clay & & & & & & & & & & & \\
\hline 74.83 & 17.28 & 7.89 & \multicolumn{2}{|c|}{44.23} & \multicolumn{2}{|l|}{1.47} & & \multicolumn{3}{|l|}{1.39} & \multicolumn{2}{|r|}{7.66} & \\
\hline
\end{tabular}

Abbreviations: $\mathrm{pH}-\mathrm{H}_{2} \mathrm{O}=$ soil hydrogenation potential in water; $\mathrm{OM}=$ organic matter; $\mathrm{N}=$ nitrogen; $\mathrm{P}=$ phosphorus; $\mathrm{K}=$ potassium; $\mathrm{Ca}=\mathrm{Calcium} ; \mathrm{Mg}=$ magnesium; $\mathrm{Na}=$ sodium; $\mathrm{H+}=$ hydrogen; $\mathrm{Al}^{3+}=$ Aluminum; $\mathrm{SB}=$ sum of bases; and $\mathrm{CEC}=$ cation exchange capacity.

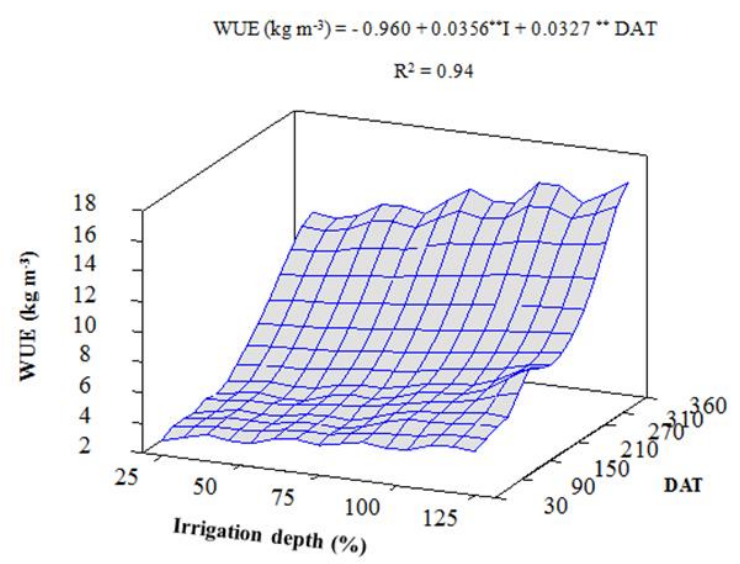

Fig 2. Water use efficiency in forage palm over ontongeny (DAT) according to the applied irrigation depths. 


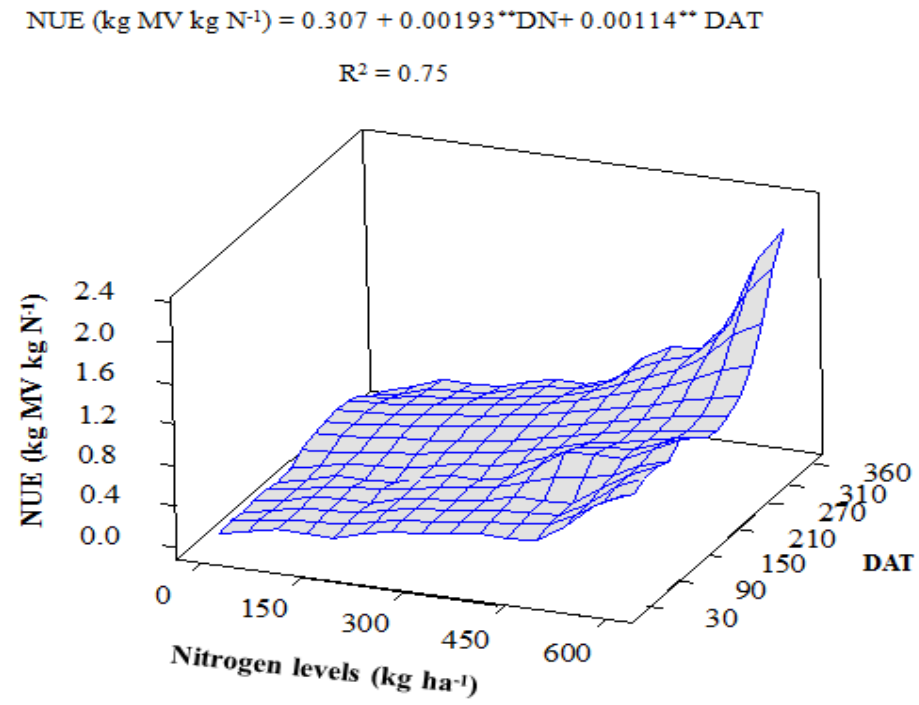

Fig 3. Efficiency of nitrogen use by forage palm to Mexican Elephant Ear cultivar as a function of different levels of nitrogen fertilization and plant ontogeny (DAT).

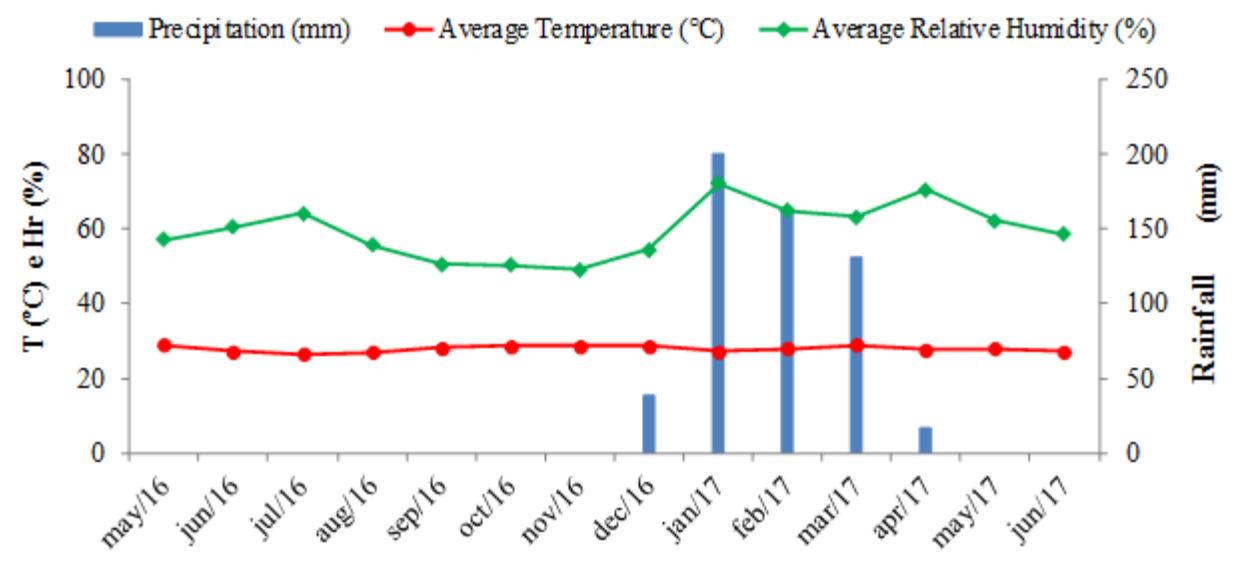

Months

Fig 4. Values of temperature, air relative humidity and rainfall in the experimental area.

influence most of agronomic indices of crop response. This fact differs from that observed in the present study since the irrigation depths influenced the growth and yield of the forage palm cultivar Mexican Elephant Ear. Hernández et al. (2004) reported that the increase in irrigation depth results in evident yield benefits for forage palm, especially in regions with reduced rainfall levels in comparison to regions, where rainfall values exceed $740 \mathrm{~mm}$. Water use efficiency in forage palm cv. Italiana in Soledade, Agreste Paraibano meso-region, was 0.61 $\mathrm{Kg} \mathrm{DM} \mathrm{m}^{-3}$ in the more densely planted system $(1.0 \times 0.5 \mathrm{~m})$ (Ramos et al., 2011). In comparison to this study, this is a quite lower value, a fact that is likely to be related to the greater availability of water provided in the present study and to the evaluated cultivar. Studies on water use efficiency in semi-arid conditions in Kingsville, Texas - USA, for Opuntia ellisiana L. forage palm showed water use efficiency equal to $393 \mathrm{~kg} \mathrm{H}_{2} \mathrm{O}$ $\mathrm{kg} \mathrm{DM}^{-1}$ (Han and Felker, 1997). Considering that fresh mass corresponds to $80 \%$ of the dry mass, the efficiency was equivalent to $11.2 \mathrm{~kg}$ of fresh mass per $\mathrm{m}^{-3}$ of water applied to the soil in the first year of cultivation, and in the fourth consecutive year, an efficiency of $285 \mathrm{~kg} \mathrm{H}_{2} \mathrm{O} \mathrm{kg} \mathrm{DM}{ }^{-1}$ was observed. This was equivalent to $17 \mathrm{~kg}$ of fresh mass per $\mathrm{m}^{-3}$ of water applied to the soil. This result is lower than that obtained in the present study with only one year of cultivation of the forage palm cultivar Mexican Elephant Ear.

In a study on sugarcane (C4 metabolism) irrigated in the semiarid region, Silva et al. (2011) obtained WUE of 5.36 and $9.49 \mathrm{~kg} \mathrm{~m}^{-3}$, considering the values of industrial yield of stalks, with the values of $R+I(R-$ rainfall and I - irrigation) and ETC (crop evapotranspiration). These results are lower than those 
obtained in the present study, and may be justified by the fact that forage palm is a Crassulacean Acid Metabolism (CAM) species and is more adapted to the semi-arid conditions. Besides, the greater efficiency in the water use, its stomata only opens during the night period (Taiz and Zaiger, 2016).

These results indicate that forage palm responds efficiently to $\mathrm{N}$ applied to soil and its availability (Rahimizadeh et al., 2010). Thus, for the definition of nitrogen use efficiency, the first stage is the availability of the element in the soil, which is essential for the development of sustainable agriculture (Cornier et al., 2013). As a result, efficiency is nothing more than the relationship between the yield of forage palm fresh matter and the amount of nitrogen available in the soil or even that applied by fertigation (Moll et al., 1982).

Queiroz et al. (2016) claimed that water use efficiency (WUE) on the fresh mass basis (MV) did not show any difference between the treatments. However, it tended to reduce its magnitude as the applied depths were increased. The average values of WUE over the analyzed period were equal to $14.0 \mathrm{~kg}$ $\mathrm{m}^{-3}$. These results are different from those observed in the present study, possibly because of the adopted management and the genetic characteristics of the cultivar used.

Silva et al. (2014) reported that water use efficiency is the biomass yield per amount of water applied or evapotranspirated. It has been commonly used for the selection of more tolerant cultivar to water stress, in which the cultivars Mexican Elephant Ear and IPA-Sertânia are the most efficient in the use of water, both in precipitated and evapotranspirated water terms. The authors report that they had obtained average water use efficiency of $11.2 \mathrm{~kg} \mathrm{~m}^{-3}$ at 24 months after planting, which is equivalent to $89.3 \mathrm{~kg} \mathrm{H}_{2} \mathrm{O} \mathrm{kg}$ $\mathrm{MV}^{-1}$ for Mexican Elephant Ear. The same was used in the present study. A solid increase in water consumption and water use efficiency by forage palm is due to nitrogen supply. A well-nourished plant becomes more efficient in the use of available water. Mochel Filho et al. (2016); Figueiredo et al. (2016); Carvalho et al. (2011) reported that nitrogen use efficiency (NUE) is an important factor in the evaluation of efficiency and sustainability of nitrogen fertilization since it estimates the dose that presented the best response. In this experiment, nitrogen use efficiency was proportional to the applied doses of $\mathrm{N}$. This result differs from that obtained by Costa et al. (2016) since they verified that the NUE was inversely proportional to the dose of applied nitrogen.

Nitrogen use efficiency linearly increased as the dose of nitrogen supplied to the soil was incremented, a fact that can be related to the gradual increase of forage palm yield and the high efficiency of the nutrient use by the crop. Sadras and Lawson (2013) reported that this rise in the NUE is due to the ability of plants to absorb and store $\mathrm{N}$ from the soil applied via fertigation.

\section{Materials and Methods}

\section{Localization and characterization of experimental area}

The experiment was conducted in field conditions in the municipality of Santa Luzia, in the western Seridó microregion of Paraíba, 06 52' 27" latitude, 36 56'00’ WGr longitude, and altitude of $299 \mathrm{~m}$, on Poço Redondo farmDuring one year of cultivation (360 days) from May 2016 to june 2017. It was implemented in the Drought Polygon, located in the Borborema Meso-region. The climate in the area is dry, hot, semi-arid Bsh with summer rains (Köppen and Geiger, 1928).

The soil in the area is classified as Floss type Neossolo (Entisol) with sandy-loam type textural classification (Embrapa, 2013), and the nitrogen content in the soil is estimated based on the organic matter. The values of some chemical, physical and water attributes of the soil are described in Table 2.

The climatic constrain of the Serido region is not the absence of rain, but its irregularity (Rodrigues, 2002). The average rainfall is about $500 \mathrm{~mm}$ where the highest concentrations are in the months from January to May. The average temperature is around $27.6^{\circ} \mathrm{C}$, with maximum and minimum averages of $33.0^{\circ} \mathrm{C}$ and $22.3^{\circ} \mathrm{C}$, respectively and relative humidity ranging from 50 to $70 \%$ (Figure 4).

The predominant vegetation in the experimental area is of the Caatinga-Seridó type, sub-verocious, deciduous vegetation whose components are mostly cacti and small trees or shrubs, usually thorny, forming groups sometimes dense or sometimes with sparse trees (Rodrigues, 2002).

Water was supplied from Amazona well, provided with C3S4 treated domestic sewage from the city of Santa Luzia, Paraíba state, located $80 \mathrm{~m}$ away from the experimental area (Silva, 2017).

\section{Experimental design, treatments and crop management}

The experimental design was a randomized block in a $5 \times 5$ factorial, where the first factor was the five irrigation depths $\left(125,100,75,50\right.$ and $\left.25 \% \mathrm{ET}_{0}\right)$, and the second, five levels of nitrogen fertilization $\left(0,150,300,450\right.$ and $\left.600 \mathrm{~kg} \mathrm{ha}^{-1} \mathrm{~N}\right)$, with three replications, totaling 75 experimental units. The average reference evapotranspiration at the experiment site was 7.6 $\mathrm{mm}$ day $^{-1}$.

The experimental plots consisted of a double row of plants with spacing of $0.4 \mathrm{~m}$ between rows, $2.0 \mathrm{~m}$ between double rows and $0.25 \mathrm{~m}$ between plants, with $5 \mathrm{~m}$ in length and a 1-m border. Each plot had an area of $14.4 \mathrm{~m}^{2}$ with a useful area of $0.6 \mathrm{~m}^{2}$ and a total area of the experiment of $3850 \mathrm{~m}^{2}$. Also, the plots with the $100 \% \mathrm{ET}_{0}$ irrigation depth had an area as twice as the plots with other depths. At that spacing, planting density for 1.0 ha was 33333 plants.

All plots of the treatments were fertilized with phosphorus and potassium according to recommendations of Santos (2006), and according to the results of soil analysis and organic fertilization using bovine manure at about $1.0 \mathrm{~kg}$ per linear meter. The nitrogen source used in the experiment was monthly split urea, applied via fertigation with the aid of a Venturi type fertilizer injector.

\section{Plant materials}

Cultivar Mexican Elephant Ear (MEE), which presents horizontal growth, abundance in dry matter, hairs and resistance to carmine cochineal (Dactylopius opuntiae), was used in the experiment. The racquets were planted in furrows with bilateral racket alignment (Dominoes). They were free 
from pests and diseases, among them the scale cochineal (Dactylopius sp). These rackets have gone through the healing period in the shade, when the cladodium loses some of the humidity and the healing of the wounds caused by the cutting operation occurs in the field.

The healing period lasted seven days, when the loss in turgidity was observed, becoming soft to the finger compression and the lesions of the cuts were healed. The rackets were arranged in furrows facing the sun (nascent) and $50 \%$ buried at 45 o of inclination (Suassuna, 1993).

\section{System characteristic and irrigation management}

The pressurized irrigation system used in the experiment had a 3 HP centrifugal pump. Regarding the start and end of the pump operation, each application cycle was performed manually, according to the start and duration of application of each depth.

A 2"-disc filter was used to prevent particulate matter larger than the diameter of the emitters from entering the system. The irrigation lateral lines were $55 \mathrm{~m}$ in length, equipped with Bourdon type gauge, calibrated and tested before irrigation. A hydrometer was installed at the beginning of the experimental area to account for the amount of water applied during the conduction of the experiment.

Irrigations were applied twice a week on the evapotranspiration basis. We used a drip type as the irrigation system, utilizing a dripping tube with wall thickness of $0.2 \mathrm{~mm}$; internal diameter of $16 \mathrm{~mm}$; drip spacing of $0.20 \mathrm{~m}$; nominal pressure of 7 m.c.a; flow rate of $6.0 \mathrm{~L} \mathrm{~h}^{-1} \mathrm{~m}^{-1}$, with a system application efficiency of $96 \%$.

The irrigation liquid layer (La), applied in each treatment was determined by the equation 1 , considering the reference evapotranspiration for the respective treatments $(125,100,75$, 50 and $25 \%$ of $\mathrm{ET}_{0}$ ). Evapotranspiration was estimated by the Penman-Monteith method recommended by FAO (Allen et al. 1998).

$L a=\left(E T_{0} * L A P\right)-R$

Where; La - irrigation liquid layer to be applied in each treatment $(\mathrm{mm}) ; \mathrm{ET}_{0}$ - reference evapotranspiration $(\mathrm{mm})$; LAP - fraction of the irrigation liquid layer applied in plot (decimal); $\mathrm{R}$ - effective rainfall in the period $(\mathrm{mm})$.

\section{Analyzed variables}

\section{Water use efficiency}

Water and nitrogen use was evaluated over a year of cultivation (360 days after planting). The sampling was performed at intervals of 30 days. Water use efficiency of the plants is usually defined as the commercial production per unit of water effectively used by the crop in the form of evapotranspiration (Jensen, 2007). Water use efficiency (WUE) was determined according to Pieterse et al. (1997), using equation 2 .

$W U E=Y / W C$

Where; WUE - water use efficiency $\left(\mathrm{kg} \mathrm{m}^{-3}\right) ; \mathrm{Y}$ - yield (kg); WC - total water consumption per cycle $\left(\mathrm{m}^{3}\right)$.
The productivity of the forage palm was determined directly in the field according to methodology proposed by Menezes et al. (2005) during the 360 days after planting. The sampling was performed every 30 days. The plants arranged in the useful areas of the plots were collected in each treatment. They were cut at the first insertion, leaving only the mother cladodium. Then, all the collected cladodes were weighed on a precision scale and sorted by plot and by treatment.

\section{Nitrogen efficiency use}

Nitrogen use efficiency was set according to the methodology proposed by Moll et al. (1982) using equation 3.

$N U E=Y / N P$

Where; NUE - nitrogen use efficiency $\left(\mathrm{kg} \mathrm{kg}^{-1}\right)$; $\mathrm{Y}$ - yield $(\mathrm{kg})$; $\mathrm{NP}$ - amount of applied nitrogen ( $\left.\mathrm{kg} \mathrm{ha}^{-1}\right)$.

\section{Statistical analysis}

Data on response variables were submitted to analysis of variance by the $\mathrm{F}$ test at $1 \%$ and $5 \%$ of significance, and the respective regression models were adjusted according to the analysis of regression variance $(\mathrm{F}<0.01)$ and to the coefficient of determination of the equation, using Minitab and Sisvar statistical software (Ferreira, 2014).

\section{Conclusions}

The determination of the optimum volume associated to water use efficiency, particularly in areas such as the semi-arid region of the Brazilian Northeast, where water resources are scarce, is fundamental for raising environmental protection. The results suggest that irrigation and adequate nitrogen fertilization may result in significant water and fertilizer savings, with no loss in forage palm yield. The accumulated $125 \% \mathrm{ET}_{0}$ depth for the Mexican Elephant Ear cultivar, drip irrigated in the Brazilian semiarid region was $818.0 \mathrm{~mm}$. Water and nitrogen use efficiency by forage palm tended to increase as water depths and nitrogen levels supplied to the soil were increased, even with the use of saline water. The $125 \% \mathrm{ET}_{0}$ depth combined with 360 days after the application of the treatments showed a higher water and nitrogen use efficiency in forage palm plants. In low nitrogen supply conditions, nitrogen use efficiency is directly and indirectly associated with the yield of forage palm fresh mass whereas under high supply, nitrogen use efficiency is more effective. The use of irrigation and nitrogen fertilization in the semi-arid region is recommended to obtain higher productivity of water and nitrogen from the forage palm.

\section{Acknowledgments}

The authors gratefully thank CNPq for the scholarship granted (grant \# 33,654,831 / 0001-36 / 2014/2015/2016) while this research was carried out (grant \# 481294 / 2013-9) to Financial support of the present research. Gratefully thank CAPES for the scholarship granted. We thank reviewers for their constructive comments. 
Allen RG, Pereira LS, Raes D, Smith S (1997) Crop evapotranspiration guidelines for computing crop water requirements. In: Gheyi HR, Sousa AA, Damasceno FAV, Medeiros JF. Roma: FAO (Irrigation and Drainage paper 56). $300 p$.

Almeida J, Peixoto CP, Ledo CAS (2012) Desempenho vegetativo e produtivo da palma forrageira. Rev Encicl Biosfera, 8(15): 571-581.

Alves RN, Farias I, Menezes RSC (2007) Produção de forragem pela palma após 19 anos sob diferentes intensidades de corte e espaçamentos. Rev Caatinga, 20(4): 38-44.

Billesbach DP (2011) Estimating uncertainties in individual eddy covariance flux measurements: a comparison of methods and a $p$ proposed new method. Agric and For Meteo, 151(3): 394-405.

Carvalho EV, Carvalho EV, Afférri FS, Peluzio JM, Leão FF, Cancellier LL, Dotto MA (2011) Eficiência do uso do nitrogênio em híbridos experimentais de milho do Programa de Melhoramento da Universidade Federal de Tocantins. Bioscience J, 27(3): 392-403.

Cormier F, Faure S, Dubreuil P, Heumez E, Beauchêne K, Lafarge S, Praud A, Le Gouis J (2013) A multi-environmental study of recent breeding progress on nitrogen use efficiency in wheat (Triticum aestivum L.). Theor and applied genetics, 126(12): 3035-3048.

Costa N L, Paulino VT, Magalhães JA, Rodigues BHN, Santos FJ S (2016) Eficiência do nitrogênio, produção de forragem e morfogênese do capim-massai sob adubação. Rev Nucleus, 13(2): 31-40.

Cunha DNFV, Gomes ES, Martuscello JA, Amorim PL, Silva CR., Ferreira PS (2012) Morfometria e acúmulo de biomassa em palma forrageira sob doses de nitrogênio. Rev Bras de Saúde Prod Anim, 13(4): 1156- 1165.

Dubeux Júnior JCB, Araújo Filho JT, Santos MVF, Lira M A, Santos DC, Pessoa RAS (2010) Adubação mineral no crescimento e composição mineral da palma forrageira Clone IPA-20. Rev Bras de Ciênc Agrárias, 5(1): 129 - 135.

Dubeux Júnior JCB, Araújo Filho JT, Santos MVF, Lira M A, Santos DC, Pessoa RAS (2013). Potential of cactus pear in South América. Cactu Newsletter,13(1): 29-40.

Embrapa - Empresa Brasileira de Pesquisa Agropecuária (2013) Sistema brasileiro de classificação de solos. 3.nd. Brasília. 353

Evett SR, Schwartz RC, Casanova JJ, Heng LK (2012) Soil water sensing for water balance, ET and WUE. Agric Water Manag, 104(1): 1-9.

Ferreira DF (2014) SISVAR: Um programa para análises e ensino de estatística. Rev Symposium, 6(2): 36-41.

FigueiredoYF, Nicole LR, Santos Jesus EO, Magiero KPF, Pimentel VA (2016) Produtividade do capim tangola (Brachiaria mutica $x$ Brachiaria arrecta) no outono sob diferentes níveis de adubação e descanso. Rev Nucleus, 13(1): 7-14.

Ghiberto PJ, Libardi PL, Brito AS, Trivelin PCO (2011) Components of the water balance in soil with sugarcane crops. Agric Water Manag, 102(1): 1-7.
Han H, Felker P(1997) Field validation of water-use efficiency of the CAM plant Opuntia ellisiana in south Texas. J of A Environ, 36(1) 133-148.

Hernández FA, Castillo IO, Amador BM, Hernández JLG, TroyoDieguez E (2004) Yield and physiological traits of prickly pear cactus 'nopal' (Opuntia spp.) cultivars under drip irrigation. Agric Water Manag,70(2): 97-107.

Jensen M E (2007) Sustainable and productive irrigated agriculture. In: Hoffman GJ, Evans RG, Jensen ME, Martin DL, Elliott RL. (Ed.). Desig. and operat. of farm irrig. systems. 2nd ed. Saint Joseph: ASABE, pp. 33-56.

Köppen W, Geiger R (1928) Klimate der Erde. Gotha: Verlag Justus Perthes. Wall-map $150 \mathrm{~cm} \times 200 \mathrm{~cm}$.

Menezes RSC, Simões DA, Sampaio EVSB (2005) A palma do Nordeste do Brasil: conhecimento atual e novas perspectivas de uso. Recife: Editora Universitária da UFPE, 2005. 258p.

Mochel Filho WJE, Carneiro MSS, Andrade AC, Pereira ES, Andrade AP, Cândido MJDC, Magalhães JA, Rodrigues BHN, Santos FJS, Costa NL (2016) Produtividade e composição bromatológica de Panicum maximum cv. Mombaça sob irrigação e adubação azotada. Rev de Ciênc Agrár, 39(1): 8188.

Moll RH, Kamprath EJ, Jackson WA(1982) Analysis and interpretation of factors which contribute to efficiency of nitrogen utilization. Agronomy J, 7(3) 562-564.

Morais DAEF, Vasconcelos AM (2007) Alternativas para incrementar a oferta de nutrientes no semiárido brasileiro. Rev Verde, 2(1): 01-24.

Payero JO, Irmak S (2008) Construction, installation, and performance of two repacked weighing lysimeters. Irrig Science, 26(2): 191-202.

Pieterse PA, Rethman NFG, Van Boch J (1997) Production, water use efficiency and quality of four cultivars of Panicum maximum Jacq. at different levels of nitrogen fertilization. Tropic Grasslands, 3(1): 117-123.

Pinheiro KM, Silva TGF, Carvalho HFS, Santos JEO, Morais JEF, Zolnier S, Santos D C(2014) Correlações do índice de área do cladódio com características morfogênicas e produtivas da palma forrageira. Rev Pesq Agrop Bras, 49(12) 939-947.

Queiroz MG, Silva TGF, Zolnier S, Silva SMS, Souza CAA, Carvalho HFS (2016) A multi-environmental study of recent breeding progress on nitrogen use efficiency in wheat (Triticum aestivum L). Rev Irriga, 5(2)141-154.

Queiroz MG, Silva TGF, Zolnier S, Silva SMS, Lima LR, Alves JO (2015) Características morfofisiológicas e produtividade da palma forrageira em diferentes lâminas de irrigação. Rev Bras Eng Agríc Ambie, 19(10)931-938.

Rahimizadeh M, Kashani A, Zare-Feizabadi A, Koocheki AR, Nassiri-Mahallati M (2010) Nitrogen use efficiency of wheat as affected by preceding crop, application rate of nitrogen and crop residues. Austr J of Crop Science, 4(5):363-368.

Ramos JPR, Leite MLMV, Oliveira Júnior $S$, Nascimento JP, Santos EM (2011) Crescimento vegetativo de opuntia ficusindica em diferentes espaçamentos de plantio. Rev Caatinga, 24(3): 41-48.

Rodrigues JL(2002) Atlas Escolar Paraíba. João Pessoa: Editora Grafset.191p. 
Sadras VO, Lawson C (2013) Nitrogen and water-use efficiency of Australian wheat varieties released between 1958 and 2007. Europ J of Agron, 46(2): 34-41.

Santos DC (2006) Manejo e utilização da palma forrageira (Opuntia e Nopalea) em Pernambuco. Recife: IPA, (IPA. Documentos, 30).48p.

Silva NGM, Lira MA, Santos MVF, Dubeux Jr J CB, Mello ACL, Silva MC (2010) Relação entre características morfológicas e produtivas de clones de palma forrageira. Rev Bras de Zootecnia, 39(11): 2389-2397.

Silva PF, Matos RM, Borges VE, Dantas Neto J, Farias MSS (2016) Morphology and biomass yield of forage cactus under mineral fertilization in organic soil. African $J$ of agri research, 11(37):3497-3505.

Silva PF (2017) Crescimento e produtividade de palma forrageira sob Diferentes lâminas de irrigação e adubação nitrogenada. Universidade Federal de Campina Grande (Tese de doutorado). 100p.

Silva TGF, Araújo Primo JT, Morais JEF, Diniz WJS, Souza CAA, Silva MC (2015) Crescimento e produtividade de clones de palma forrageira no semiárido e relações com variáveis meteorológicas. Rev Caatinga, 28(2): 10-18.

Silva TGF, Araújo Primo JT, Silva SMS, Moura MSB, Santos DC, Silva MC, Araújo JEM (2014) Indicadores de eficiência do uso da água e de nutrientes de clones de palma forrageira em condições de sequeiro no Semiárido brasileiro. Rev Bragantia,73(2):184-191.

Silva TGF, Moura MSB, Zolnier S, Soares JM, Vieira VJS, Farias Júnior WG (2011) Demanda hídrica e eficiência do uso de água da cana-de-açúcar irrigada no semiárido brasileiro. Rev Bras Eng Agríc Ambie, 15(12):1257-1265.

Souza L S B, Moura MSB, Sediyama GC, Silva TGF (2011) Eficiência do uso da água das culturas do milho e do feijãocaupi sob sistemas de plantio exclusivo e consorciado no semiárido brasileiro. Revi Bragantia, 70(3) 715-721.

Suassuna P (1993) Lucratividade da Cultura da Palma Forrageira na Paraíba. http// www.joaosuassuna.hpg.ig.com.br/sistprod.htm-5k(acessado e 16.07.16).

Taiz L, Zeiger E(2013) Fisiologia vegetal. 5.nd. Porto Alegre:Artemed, 954p. 